\title{
Perancangan Alat Uji Impak Digital dengan Metode Charpy Untuk Mengukur Kekuatan Material Polimer
}

\author{
Yhudo Nuhgraha ${ }^{1 *}$, M.Khairul Amri Rosa ${ }^{2}$, Indra Agustian ${ }^{3}$ \\ 1,2,3 Teknik Elektro Universitas Bengkulu, yhudonuhgraha44@gmail.com
}

\begin{abstract}
ABSTRAK
Pada penelitian ini dilakukan pembuatan alat uji impak metode Charpy secara digital dengan menggunakan sensor rotary encoder dan mikrokontroler. Uji impak merupakan salah satu metode yang digunakan untuk mengetahui kekerasan, kekuatan serta keuletan material. Untuk mengetahui keakuratan alat uji impak yang telah dibuat maka dilakukan perbandingan antara alat uji impak otomatis dengan alat uji impak manual. Hasil pengujian menunjukkan bahwa alat uji impak digital otomatis yang dirancang memiliki performa yang lebih baik dibandingkan dengan pengujian manual.
\end{abstract}

Kata kunci: uji impak digital, metode charpy, material polimer

\section{Pendahuluan}

Material merupakan salah satu kebutuhan yang mendasar untuk suatu konstruksi. Dengan berbagai macam kebutuhan sifat mekanik yang dibutuhkan oleh suatu material adalah berbeda-beda. Sifat mekanik tersebut terutama meliputi kekerasan, keuletan, kekuatan, ketangguhan, sifat mampu las serta sifat mampu mesin yang baik. Dengan sifat pada masing-masing material berbeda, maka banyak metode untuk menguji sifat yang dimiliki oleh suatu material tersebut. Uji impak merupakan salah satu metode yang digunakan untuk mengetahui kekuatan, kekerasan, serta keuletan material.

Pengujian impak merupakan suatu upaya untuk mensimulasikan kondisi operasi material yang sering ditemui dalam perlengkapan transportasi atau konstruksi dimana beban tidak selamanya terjadi secara perlahanlahan melainkan datang secara tiba-tiba $[1,2]$. Untuk menampung dinamika ini perlu pengujian dalam skala besar, baik jumlah maupun dimensi. Tetapi dipandang dari sudut ekonomi hal ini tidak mungkin dilakukan. Karena itu, dibuat pengujian dalam skala kecil yang distandarkan yang disebut pengujian takik. Pengujian yang dilakukan dalam skala kecil pada umumnya adalah uji impact metode Charpy [3, 4, 5].

Kurangnya teknologi yang diperoleh pada pengujian impak ini menyebabkan pada saat melakukan pengujian

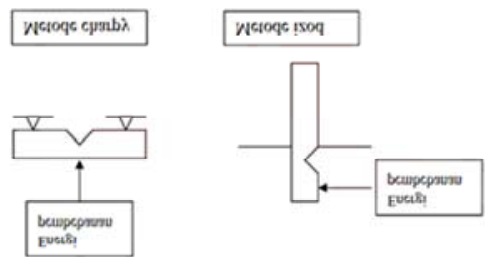

Gambar 1. Uji Impak Charpy dan Izod

material terdapat masalah yang cukup kompleks tentang ketelitian bahkan rentan waktu yang di perlukan untuk perhitungan pada pengujian impak.

Pengujian impak yang masih banyak dilakukan secara manual dalam menghitung seberapa kuat material yang telah diuji, mengakibatkan pengujian terkadang menjadi kurang teliti. Maka pada penelitian ini dirancang alat uji impak digital dengan memanfaatkan sensor rotary encoder [6] dan mikrokontroler untuk dapat melakukan pengukuran secara otomatis.

\section{TINJAUAN PUSTAKA}

\section{A. Uji Impak}

Uji impak merupakan pengujian suatu bahan untuk mengetahui apakah suatu material apakah rapuh atau ulet dari segi ketangguhannya. Pengujian impak ini akan mendeteksi perbedaan yang tidak bisa dibaca melalui tegangan regangan dan juga hasil yang di dapatkan tidak bisa dibaca secara langsung dengan kondisi perpatahan batang uji, hal ini disebabkan karena pengujian impak tidak dapat mengukur gaya tiga dimensi.

Metode uji impak ada 2, seperti ditunjukkan pada Gambar 1, yaitu uji impak metode Charpy dan metode Izod [7, 8]. Metode Charpy banyak digunakan di Amerika Serikat, sedangkan metode Izod banyak digunakan di Eropa. Batang uji metode Charpy memiliki spesifikasi, luas penampang $10 \mathrm{~mm} \times 10 \mathrm{~mm}$ dan takikan berbentuk V. Proses pembebanan uji impak pada metode charpy dan metode izod dengan sudut $45^{\circ}$, kedalaman takik $2 \mathrm{~mm}$ dengan radius pusat $0.25 \mathrm{~mm}$.

Batang uji charpy kemudian diletakkan horizontal

pada batang penumpu dan diberi beban secara tiba-tiba dibelakang sisi takik oleh pendulum berat berayun (kecepatan pembebanan $\pm 5 \mathrm{~m} / \mathrm{s}$ ). Batang uji diberi energi 
untuk melengkung sampai kemudian patah pada laju regangan yang tinggi hingga orde $\left.10^{3} \mathrm{~s}\right\urcorner$. Batang uji izod, lebih banyak dipergunakan saat ini, memiliki luas penampang berbeda dan takik berbentuk $\mathrm{v}$ yang lebih dekat pada ujung batang. Dua metode ini juga memiliki perbedaan pada proses pembebanan.

\section{B. Spesimen Uji}

Pada pengujian impak dengan metode Charpy, benda uji (spesimen) berdimensi mempunyai luas penampang bujur sangkar $10 \mathrm{~mm}$ x $10 \mathrm{~mm}$ dengan panjang $55 \mathrm{~mm}$. Pada benda uji dibuat takikan tepat di tengahnya dengan bentuk takikan $\mathrm{V}-45^{\circ}$ dengan kedalaman $2 \mathrm{~mm}$ dan jari-jari dasar $0,25 \mathrm{~mm}$. Benda uji diletakkan mendatar dengan takik membelakangi pendulum penghantam dengan kecepatan impak rata-rata kisaran $3 \mathrm{~m} / \mathrm{s}-6 \mathrm{~m} / \mathrm{s}$.

Kendala plastik pada takik menghasilkan keadaan regangan tiga sumbu. Konsentrasi tegangan plastik maksimum diberikan oleh persamaan:

$$
K a=\left(1+\frac{\pi}{2}-\frac{\omega}{2}\right)
$$

Dimana $\omega$ sudut antara sisi takik. Nilai relative ketiga tegangan utama sangat tergantung pada dimensi batang dan ukuran takik. Benda uji standar cukup tebal untuk menjamin pembebanan regangan bidang yang tinggi dan terbentuknya regangan tiga sumbu pada hampir diseluruh penampang lintang takik.

Dengan dimensi benda uji takik V Charpy standar, memberikan kondisi yang baik bagi pengujian patah getas. Maka diperoleh rumus energi impak:

$E I=m g R(\cos \beta-\cos \alpha)$

dengan harga impak:

$H I=\frac{E I}{A}$

dengan,

$\mathrm{EI}=$ Energi impak $(\mathrm{J})$

$\mathrm{M}=$ Massa $(\mathrm{kg})$

$\mathrm{g}=$ Gravitasi $\left(\mathrm{m} / \mathrm{s}^{2}\right)$

$\mathrm{R}=$ Jari-jari (m)

$\beta=$ Sudut pengukuran

$\alpha=$ Sudut awal ketentuan

$\mathrm{A}=$ Luas Penampang $\left(\mathrm{m}^{2}\right)$

$\mathrm{HI}=$ Harga Impak $\left(\mathrm{J} / \mathrm{mm}^{2}\right)[5]$.

\section{Penelitian Terkait}

Fery Hardiana dkk [9], pada tahun 2007, merancang alat uji impak metode Charpy dan Izod. Ketangguhan (impak) merupakan ketahanan bahan terhadap beban kejut. Inilah yang membedakan pengujian impak dengan pengujian tarik dan kekerasan dimana pembebanan dilakukan secara perlahan-lahan. Pengujian impak merupakan suatu upaya untuk mensimulasikan kondisi operasi material yang sering ditemui dalam perlengkapan transportasi atau konstruksi dimana beban tidak selamanya terjadi secara perlahan-lahan melainkan datang secara tiba-tiba. Dari hasil penelitian maka dibuat pengujian dalam skala kecil yang distandarkan yang disebut pengujian takik. Pengujian ini pada umumnya adalah uji impak Charpy untuk mengetahui tingkat kegetasan dan harga impak material. Kelemahan alat ini masih melakukan pengukuran dan perhitungan secara manual jadi masih membutuhkan waktu yang tidak cepat.

Chaerul Umam Wardani dkk [10], pada tahun 2009, menganalisis pengujian impak metode Izod dan Charpy menggunakan benda uji aluminium dan baja ST37. Uji impak merupakan salah satu metode yang digunakan untuk mengetahui kekuatan, kekerasan, serta keuletan material. Oleh karena itu uji impak banyak digunakan dalam bidang menguji sifat mekanik yang dimiliki oleh suatu material tersebut. Pada pengujian yang telah dilakukan pada kedua alat uji yang berbeda perpatahan yang terjadi pada aluminium dan baja adalah ulet akan tetapi untuk baja harga impak lebih tinggi karena baja mempunyai ketangguhan. Sedangkan untuk benda uji harga impak berbeda karena ada beberapa faktor yang menyebabkan perbedaan dari ukuran benda uji, berat bandul, panjang lengan bandul, dan perbedaan dari sudut awal bandul

Hasrin [11], pada tahun 2010, menganalisis perpatahan baja ST60 yang dikenai beban impak Charpy. Pengujian yang dilakukan untuk memperkirakan ketangguhan suatu bahan dapat juga dilakukan dengan mengamati bentuk permukaan patah, dimana semakin besar persentase perpatahan berserat menandakan bahan terebut semakin ulet yang berarti semakin tangguh pula suatu material. Sebaliknya jika semakin halus dan datar permukaan patahannya, maka material tersebut semakin getas dan rapuh. Material yang getas dapat juga ditandai dengan permukaan patah berbentuk kristalin yang menghasilkan pantulan cahaya atau sering disebut mekanisme pembelahan.

\section{Metode Penelitian}

Penelitian dilaksanakan pada bulan agustus 2018 di lingkungan Gedung Laboratorium Teknik Elektro Fakultas Teknik Universitas Bengkulu. Penelitian ini dilaksanakan secara bertahap dengan tahap awal mempelajari metode dan teori-teori yang berhubungan dengan mikrokontroler, sensor-sensor, serta sistem yang terkait di dalamnya yang dilanjutkan dengan perencanaan, pembuatan alat dan laporan serta analisa sistem.

Pada Gambar 2 ditunjukkan blok diagram sederhana alat uji impak digital, dengan peralatan utama yang digunakan yaitu :

1. Alat uji impak mekanik 


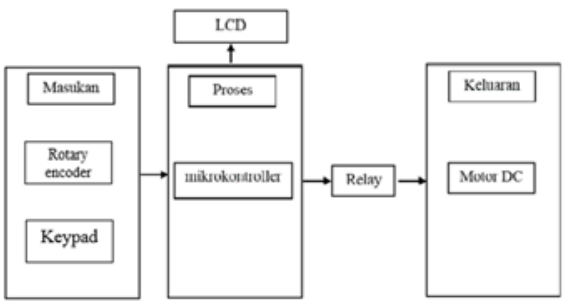

Gambar 2. Blok diagram sistem

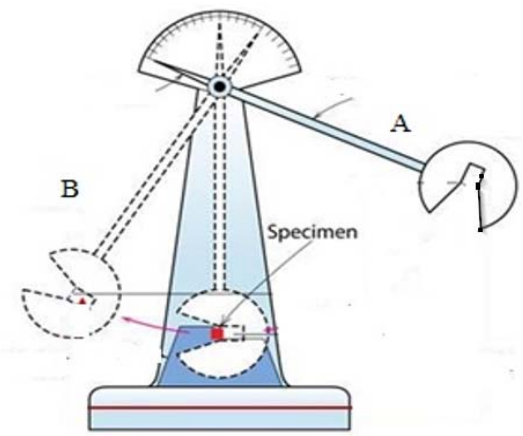

Gambar 3. Uji Impak mekanik dengan mekanisme bandul
2. Arduino Uno
3. Rotary encoder
4. LCD
5. Motor DC
6. Keypad

Pada Gambar 3, terdapat bandul yang digunakan untuk menumbuk spesimen pengujian material. Pada busur skala juga terdapat 2 jarum yang berfungsi sebagai petunjuk perpindahan sudut. Pada perancangan alat uji impak otomatis, mikrokontroler dipasangkan untuk mengetahui seberapa besar gaya impak yang dihasilkan untuk menumbuk sebuah material. Untuk mengetahui secara digital saat bandul bergerak berpindah untuk menumbuk material maka pada jarum skala yang bergerak sebagai penanda perpindahan sudut dipasangkan sensor rotary encoder sebagai sensor untuk mendapatkan data perpindahan sudutnya.

Saat bandul bergerak menumbuk sebuah material, maka sensor rotary yang dipasang tersebut akan menangkap data perpindahan sudut berdasarkan pergerakan bandul uji impak yang akan di proses oleh mikrokontroler untuk melakukan perhitungan dengan menggunakan persamaan (3) untuk mengetahui berapa nilai uji impak pada sebuah material yang diuji.

Tahap selanjutnya mengganti spesimen uji dengan material yang sama namun menggunakan benang yang berbeda beserta takaran katalis yang di bedakan untuk mendapatkan keras material yang beragam berfungsi sebagai perbandingan material. Pada percobaan ini dilakukan percobaan 15 kali dengan 5 material yang memiliki jumlah benang berbeda dan dengan kandungan katalis yang berbeda pula.

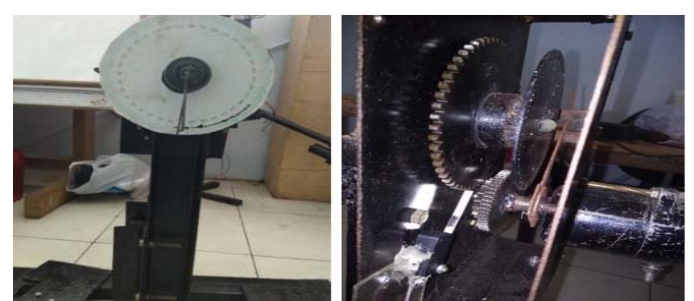

Gambar 4. Mekanik Uji Impak

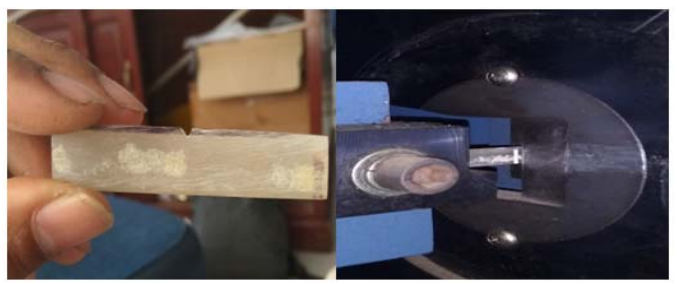

Gambar 5. Spesimen Uji dan Posisi Peletakan

Berikut ini langkah yang dilakukan dalam pengujian uji impak dengan alat yang dirancang:

1. Set nilai $\alpha$ (set point) sebagai sudut awal pengukuran perpindahan lengan pada alat uji impak Charpy dan lengan terangkat sesuai dengan nilai set point $(\alpha)$ yang sudah ditetapkan. Pada pengujian ini digunakan nilai $140^{\circ}$.

2. Saat lengan pendulum telah dalam posisi siap (set point), maka pengunci lengan di lepas agar lengan pendulum berayun menumbuk spesimen yang telah diletakkan pada tatakan spesimen pengujian.

3. Setelah lengan berhenti berayun maka dapat dilihat pada tampilan LCD berapa nilai energi impak beserta nilai sudut perolehan $(\beta)$ dan sudut $(\alpha)$.

\section{HASIL dAN PEMbahasan}

Kerangka uji impak memiliki bahan dasar material besi plat yang bentuknya menyesuaikan pergerakan lengan impak dan dudukan pada material tertumbuk. Kerangka mekanik uji impak dapat dilihat pada Gambar 4. Pada gambar dapat dilihat pada kerangka uji impak telah terpasang lengan yang di fungsikan untuk menumbuk seperti pada Gambar 3. dan selanjutnya terdapat dudukan spesimen pengujian yang akan ditumbuk oleh lengan. Pada gambar selanjutnya terdapat plat yang telah di pasangkan stiker derajat yang berfungsi sebagai indikator saat lengan terangkat agar lengan terangkat sesuai dengan sudut yang telah di tentukan. Dapat terlihat juga gear box yang telah terpasang berfungsi sebagai pengangkat lengan dengan menggunakan motor DC. Motor dc yang digunakan memiliki spesifikasi tegangan $12 \mathrm{~V}$ dengan torsi $\pm 10 \mathrm{~kg}$ dan juga arus 6A dalam kondisi tanpa beban. 


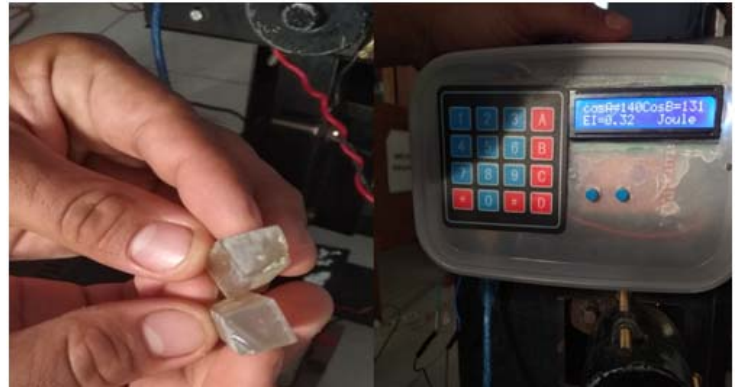

Gambar 6. Sampel patahan material uji impak dengan katalis $0.1 \mathrm{ml}$ dan data EI pada LCD alat

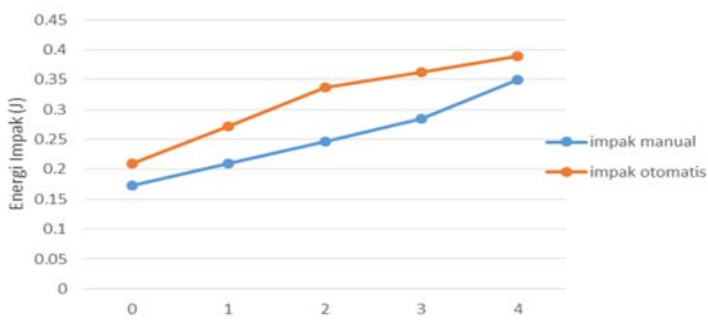

Gambar 7. Grafik Uji Impak dengan katalis $0.1 \mathrm{ml}$

Pada Gambar 5 ditunjukkan bentuk takikan yang dibuat untuk percobaan dan peletakan spesimen pengujian. Prosedur pengujian dilakukan setelah dibuat spesifikasi untuk spesimen pengujian berbahan dasar resin yang di campur dengan katalis sesuai dengan komposisi yang sudah ditentukan dengan membedakan komposisi katalis dari $0,1 \mathrm{ml}, 0,2 \mathrm{ml}$ dan $0,3 \mathrm{ml}$. dan memvariasikan banyaknya serat benang yang diisikan ke dalam spesimen pengujian. Sampel Hasil pengujian impak ditunjukkan pada Error! Reference source not found.

\section{A. Pengujian alat uji impak dengan katalis $0,1 \mathrm{ml}$.}

Pengujian ini dilakukan untuk mendapatkan data yang akan dibandingkan dengan alat uji impak yang ada di laboratorium teknik mesin Universitas Bengkulu. Alat uji impak dengan beban $1 \mathrm{~kg}$ dan panjang lengan $0,3 \mathrm{~m}$ dan dengan nilai gravitasi $9,8 \mathrm{~m} / \mathrm{s}$ dengan komposisi katalis $0,1 \mathrm{ml}$ dan serat benang satu hingga serat benang empat.

Perbedaan banyak katalis mempengaruhi kekuatan dan kekerasan spesimen dan ditunjang dengan perbedaan serat benang. Hal ini dapat dilihat dari perbedaan data nilai sudut dan hasil energi impak yang diperoleh pada setiap percobaan. Perbandingan hasil pengujian otomatis dengan manual ditunjukkan pada Error! Reference source not found.. Data pada

pengujian katalis $0,1 \mathrm{ml}$ memiliki data terendah saat pengujian otomatis dengan tanpa serat dengan nilai pengujian impak 0,21 joule dan dengan data tertinggi pada 4 serat dengan nilai uji impak 0,3887 joule.

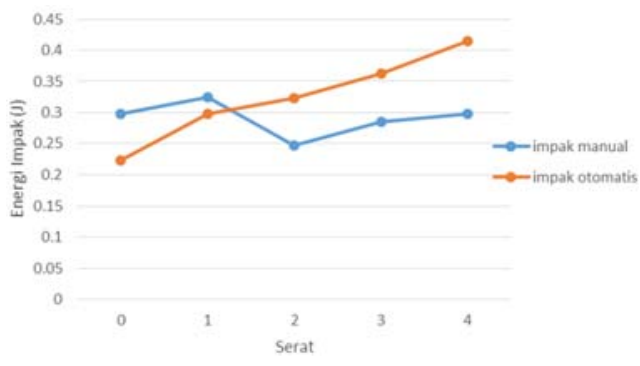

Gambar 8. Grafik Uji Impak denga katalis $0.2 \mathrm{ml}$

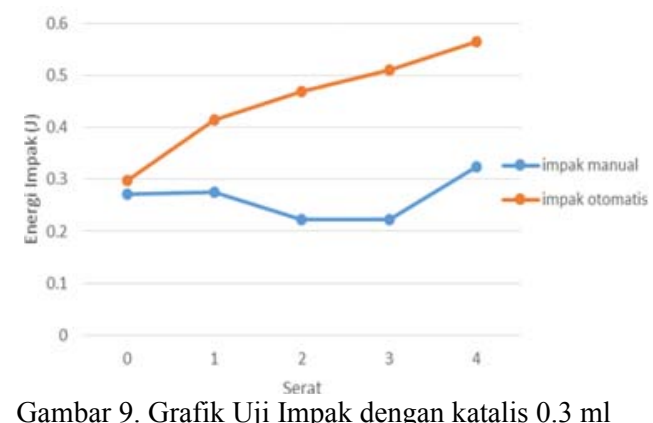

B. Pengujian alat uji impak dengan katalis $0,2 \mathrm{ml}$.

Pengujian kedua dilakukan dengan komposisi katalis $0,2 \mathrm{ml}$ dengan berat lengan $1 \mathrm{~kg}$. Pengambilan data telah dilakukan, data pengujian impak dengan katalis 0,2 $\mathrm{ml}$ dan dengan variasi serat benang dari serat 0 hingga 4 . Perbandingan hasil pengujian otomatis dengan manual ditunjukkan pada Error! Reference source not found. Data terendah pengujian otomatis pada nilai rata - rata tanpa serat dengan nilai 0,324 joule hal ini dikarenakan spesimen pada percobaan pertama menggunakan tanpa serat. Sebaliknya semakin banyak serat maka nilai impak akan semakin besar.

\section{Pengujian alat uji impak dengan katalis $0,3 \mathrm{ml}$}

Pengujian ketiga menggunakan komposisi katalis $0,3 \mathrm{ml}$. Data yang diperoleh adalah 12 data dengan 4 variasi serat benang. Dengan menggunakan beban lengan $1 \mathrm{~kg}$ dan panjang lengan $0,3 \mathrm{~cm}$. untuk nilai gravitasi yang digunakan untuk menghitung energi impak sesuai dengan persamaan (2) maka nilai gravitasi tetapan adalah $9,8 \mathrm{~m} / \mathrm{s}$.

Dengan 5 variasi isi benang yang terdapat pada spesimen percobaan. Dan pengujian dilakukan untuk memperoleh rata - rata pada nilai energi impak untuk hasil pengujian impak. Perbandingan hasil pengujian otomatis dengan manual ditunjukkan pada Error! Reference source not found.. Data pengujian menunjukkan data terendah pada nilai rata - rata tanpa 
serat dengan nilai 0,451 joule hal ini dikarenakan spesimen pada percobaan pertama menggunakan tanpa serat. Sebaliknya semakin banyak serat maka nilai impak akan semakin besar.

\section{KESIMPULAN}

Pada penelitian ini dirancang alat uji metode Charpy dengan sistem pencatatan secara digital. Komponen

utama terdiri mekanik uji impak, sensor rotary encode dan mikrokontroler. Dari ketiga data hasil pengujian, terlihat bahwa alat uji impak digital otomatis yang dirancang memiliki data hasil pengujian yang lebih baik dibandingkan dengan pengujian manual. Dengan semakin banyak serat data yang dihasilkan energi impak yang dihasilkan akan semakin besar, hal ini sesuai dengan yang ditunjukkan pada data pengujian uji impak yang dirancang, berbeda dengan pengujian manual masih terdapat ketidakakuratan bacaan. Maka dengan ini dapat disimpulkan bahwa alat uji impak digital yang dirancang memilik performa kerja yang lebih baik dibandingkan dengan sistem manual.

\section{DAFTAR Pustaka}

[1] Y. Handoyo, "Perancangan alat uji impak metode charpy kapasitas 100 joule," Jurnal Ilmiah Teknik Mesin Unisma" 45" Bekasi, vol. 1, p. 97950, 2013.

[2] F. Taheri-Behrooz, M. Shokrieh and H. Abdolvand, "Designing and manufacturing of a drop weight impact test machine," Engineering Solid Mechanics, vol. 1, pp. 69-76, 2013.

[3] A. Rossoll, C. Berdin, P. Forget, C. Prioul and B. Marini, "Mechanical aspects of the Charpy impact test," Nuclear engineering and design, vol. 188, pp. 217-229, 1999.
[4] K. Toshiro, Y. Isamu and N. Mitsuo, "Evaluation of dynamic fracture toughness parameters by instrumented Charpy impact test," Engineering Fracture Mechanics, vol. 24, pp. 773-782, 1986.

[5] R. A. Wullaert, "Applications of the instrumented Charpy impact test," in Impact Testing of Metals, ASTM International, 1970.

[6] K. Miyashita, T. Takahashi and M. U. N. E. S. A. D. A. Yamanaka, "Features of a magnetic rotary encoder," IEEE Transactions on Magnetics, vol. 23, pp. 2182-2184, 1987.

[7] N. L. Hancox, "Izod impact testing of carbon-fibrereinforced plastics," Composites, vol. 2, pp. 41-45, 1971.

[8] N. Saba, M. Jawaid and M. T. H. Sultan, "An overview of mechanical and physical testing of composite materials," in Mechanical and Physical Testing of Biocomposites, Fibre-Reinforced Composites and Hybrid Composites, Elsevier, 2019, pp. 1-12.

[9] F. Hardiana, H. Budiman and Y. Samantha, "Perancangan Alat Uji Impak Metode Charpy Dan Izod," PROCEEDING STIMA, 2016.

[10] C. U. Wardani, Y. Samantha and H. Budiman, "Analisis Pengujian Impak Metoda Izod Dan Charpy Menggunakan Benda Uji Alumunium Dan Baja St37," PROCEEDING STIMA, 2016.

[11] Hasrin, "Analisa Perpatahan Baja ST 60 Yang Dikenai Beban Impak Charfy," in Seminar Nasional Yusuf Benseh Politeknik Negeri Lhokseumawe, Lhokseumawe, Aceh, 2013.

[12] C. M. Tai, R. K. Y. Li and C. N. Ng, "Impact behaviour of polypropylene/polyethylene blends," Polymer Testing, vol. 19, pp. 143-154, 2000. 